MaPan : Jurnal Matematika dan Pembelajaran

p-ISSN: 2354-6883 ; e-ISSN: 2581-172X

Volume 6, No 1, June 2018 (82-93)

DOI: https://doi.org/10.24252/mapan.2018v6n1a8

\title{
MODEL PEMBELAJARAN KOOPERATIF TALKING STICK, MIND MAPPING, DAN KEMAMPUAN KOMUNIKASI MATEMATIS
}

\author{
Ida Ayu Dewi Wulandari11), I Made Suarsana2), I Gusti Ngurah Pujawan') \\ 1,2,3Universitas Pendidikan Ganesha \\ 1,2,3 Jl. Udayana Singaraja, Singaraja - Bali, Indonesia \\ E-mail: ida.ayu@gmail.com ${ }^{1}$, suarsana1983@gamil.com²), igusti.pujawan@gmail.com ${ }^{3)}$
}

Submitted: 24-03-2018, Revised: 21-05-2018, Accepted: 22-05-2018

\begin{abstract}
Abstrak:
Penelitian ini bertujuan untuk mengetahui apakah kemampuan komunikasi matematika siswa yang belajar dengan menggunakan model pembelajaran talking stick berbantuan mind mapping lebih baik daripada kemampuan komunikasi matematika siswa yang belajar dengan menggunakan pembelajaran konvensional. Jenis penelitian ini adalah eksperimen semu dengan desain penelitian post test only control group design. Populasi penelitian adalah seluruh siswa kelas VIII non unggulan semester genap SMP Negeri 6 Singaraja tahun ajaran 2016/2017 dengan jumlah 293 siswa. Pengambilan sampel dilakukan dengan teknik purposive random sampling. Data kemampuan komunikasi matematis siswa dikumpulkan dengan tes essay yang terdiri dari 5 butir soal. Data yang terkumpul selanjutnya dianalisis menggunakan uji-t. Hasil analisis data menunjukkan bahwa kemampuan komunikasi matematika siswa yang belajar dengan menggunakan model pembelajaran talking stick berbantuan mind mapping lebih baik daripada kemampuan komunikasi matematika siswa yang belajar dengan menggunakan pembelajaran konvensional.
\end{abstract}

Kata Kunci: Talking Stick, Mind Mapping, Kemampuan Komunikasi Matematika

\section{TALKING STICK COOPERATIVE LEARNING MODEL, MIND MAPPING AND MATHEMATICAL COMMUNICATION SKILL}

\begin{abstract}
:
This study aims to determine whether the mathematical communication skills of students who learn by using learning models talking stick with mind mapping is better than the mathematical communication skills of students who learn by using conventional learning. This research type is quasi-experiment with research design Post Test Only Control Group Design. The study population is all students of Non-Superior Class VIII Junior High School 6 Singaraja Academic Year 2016/2017 with the number of 293 students. Sampling was done by purposive random sampling technique. Data of students' mathematical communication ability were collected by essay test consisting of 5 items. The collected data is then analyzed using the t-test. The results of data analysis showed that the mathematical communication ability of students who learn by using learning model talking stick with Mind mapping is better than the mathematics communication ability of students who learn by using conventional learning.
\end{abstract}

Keywords: Talking Stick, Mind Mapping, Mathematics Communication 
How to Cite: Wulandari, I. A. D., Suarsana, I. M., \& Pujawan, I. G. N. (2018). Model Pembelajaran Kooperatif Talking Stick, Mind Mapping, dan Kemampuan Komunikasi Matematis. MaPan : Jurnal Matematika dan Pembelajaran, 6 (1), 82-93.

$\longrightarrow$ alah satu tujuan pembelajaran matematika di sekolah adalah untuk membekali siswa dengan kemampuan mengkomunikasikan gagasan dengan simbol, tabel, diagram, atau media lain untuk memperjelas keadaan atau masalah (Nasional, 2006). Pernyataan tersebut menegaskan bahwa kemampuan komunikasi merupakan bagian penting dalam pembelajaran matematika. (Baroody, 1993) menyebutkan bahwa sedikitnya ada dua alasan penting mengapa komunikasi dalam pembelajaran matematika perlu dikembangkan di sekolah yaitu (1) mathematics is essentially a language, dan (2) mathematics and mathematics learning are, at heart, social activities. Ahli lain (Sullvian, 1996) juga menegaskan bahwa komunikasi matematika bukan hanya sekedar menyatakan ide melalui tulisan tetapi lebih luas lagi yaitu kemampuan siswa dalam bercakap, menjelaskan, menggambarkan, mendengar, menanyakan, klarifikasi, bekerja sama (sharing), menulis, dan akhirnya melaporkan apa yang telah dipelajari. Sementara menurut Syahri (2017) komunikasi dalam matematika adalah suatu aktivitas penyampaian dan atau penerimaan gagasan-gagasan matematika dalam bahasa matematika. Penyampaian ide-ide atau gagasan menggunakan simbol-simbol, notasi-notasi dan lambang-lambang merupakan salah satu kemampuan komunikasi matematika. Dengan demikian komunikasi matematika merupakan kemampuan siswa dalam menyampaikan ide secara lisan atau tertulis, serta kemampuan siswa dalam menginterpretasikan gambar, grafik, tabel, dan sajian fisik.

Menurut (Shiel, 2007) kemampuan komukasi matematis juga menjadi salah satu bagian yang diukur dalam domain kognitif pada survey internasional literasi matematika Program International Students Achievement (PISA). Hasil PISA terakhir, menunjukkan bahwa peringkat siswa Indonesia adalah 63 dari 70 negara (OECD, 2016). Terpuruknya prestasi dalam survey internasional ini mengindikasikan masih lemahnya kemampuan komunikasi matematis siswa. Kemampuan komunikasi matematis merupakan elemen penting dalam pembentukan kompetensi matematika siswa namun penguasaannnya masih rendah. Perlu dilakukan inovasi pada pembelajaran matematika di kelas yang berdampak langsung pada peningkatan kemampuan komunikasi matematika. Menurut (Sumarno, 2010) untuk 
mengembangkan kemampuan komunikasi matematis siswa, pembelajaran matematika perlu memberikan penekanan pada kegiatan yang membiasakan siswa untuk (1) menyatakan suatu situasi, gambar, diagram, atau benda nyata ke dalam bahasa, simbol, ide, atau model matematik; (2) menjelaskan ide, situasi, dan relasi matematis secara lisan atau tulisan; (3) mendengarkan, berdiskusi, dan menulis tentang matematika; (4) membaca dengan pemahaman suatu representasi matematis tertulis; (5) membuat konjektur, menyusun argumen, merumuskan definisi, dan generalisasi; (6) mengungkapkan kembali suatu uraian atau paragraf matematika dalam bahasa sendiri.

Menurut (Maisura \& Jannah, 2016) penyebab masih rendahnya kemampuan komunikasi matematis siswa adalah kurangnya kesempatan yang diberikan kepada siswa untuk mengungkapkan ide dan gagasannya dalam wujud lisan dan tulisan. Model pembelajaran yang dapat mengakomodasi hal ini adalah model pembelajaran kooperatif talking stick. Model pembelajaran kooperatif ini dapat mendorong terjadinya komunikasi yang aktif melalui kegiatan diskusi, pengajuan pertanyaan, mendengarkan secara aktif dan mempresentasikan, yang teknisnya dilakukan dengan bantuan stick dengan panjang $20 \mathrm{~cm}$. Siswa yang memegang stick wajib menjawab pertanyaan dari guru setelah siswa mempelajari materi pokoknya. Selain untuk melatih berbicara dan mengemukakan pendapatnya, pembelajaran ini akan menciptakan suasana yang menyenangkan dan membuat siswa aktif.

Pada langkah awal dalam model pembelajaran talking stick, guru hanya menginformasikan materi pokok saja, dan siswa diminta untuk mempelajari sendiri sebelum tongkat akan dikelilingkan. Bagi siswa yang tidak cepat memahami materi pelajaran, hal ini akan membuat siswa merasa khawatir ketika giliran tongkat berada pada tangannya dan siswa tersebut tidak dapat menjawab pertanyaan dari guru. Hal ini dikarenakan kurangnya persiapan dalam memahami materi. Oleh karena itulah dalam proses pembelajarannya perlu adanya bantuan mind mapping. Menginformasikan materi melalui bagan yang dinamakan dengan mind mapping sehingga dalam langkah awal pembelajaran membantu siswa lebih memahami dan mengingat materi. Selain itu, siswa juga diminta untuk melatih diri dalam membuat mind mapping. Menurut (Iwan, 2004), mind mapping (peta pikiran) adalah teknik meringkas konsep yang telah dipelajari dan memproyeksikan masalah yang dihadapi ke dalam bentuk peta atau teknik grafik sehingga lebih mudah memahaminya, 
sedangkan menurut (Windura, 2008), mind mapping merupakan teknik grafis yang memungkinkan kita untuk mengeksplorasi seluruh kemampuan otak untuk keperluan berpikir dan belajar. Berdasarkan uraian tersebut, mind mapping dapat diartikan sebagai suatu teknik pembelajaran yang memanfaatkan kerja alami otak kanan dan otak kiri secara seimbang melalui proses mencatat dan meringkas yang dapat membantu mengingat perkataan, bacaan, meningkatkan pemahaman terhadap materi, membantu mengorganisasikan materi dan memberikan wawasan baru.

Perpaduan antara model pembelajaran talking stick dengan mind mapping dalam pembelajaran matematika dapat dilihat pada tahap pembelajarannya, yaitu guru menginformasikan materi secara singkat dalam bentuk bagan-bagan yang dinamakan dengan mind mapping dan siswa perlu memahami materi tersebut. Sembari memahami penjelasan dari guru, siswa diberikan kesempatan untuk membaca kembali dan berdiskusi dengan anggota kelompoknya, kemudian guru melaksanakan tahap pada model pembelajaran talking stick yaitu meminta siswa yang memperoleh giliran memegang stick untuk mengomunikasikan atau menjawab pertanyaan yang diberikan oleh guru, untuk pembelajaran/langkah selanjutnya siswa diminta untuk melatih diri dalam membuat mind mapping atau mengkonstruksi pengetahuannya sendiri yang didapat dari proses sebelumnya yang dituangkan dalam bentuk mind mapping secara berkelompok. Dengan demikian, siswa mampu memahami sendiri bagaimana materi yang akan dipelajari, dapat menuliskan struktur, notasi, ataupun istilah-istilah dengan benar dalam sebuah mind mapping. Melalui latihan dalam membuat mind mapping merupakan langkah dalam menuliskan kembali ide matematika dengan bahasanya sendiri yang mencerminkan dalam kemampuan komunikasi siswa secara tertulis.

Hasil penelitian (Yunita, 2014) menunjukan bahwa kemampuan komunikasi matematika siswa yang belajar dengan menggunakanmodel pembelajaran kooperatif talking stick memperoleh hasil yang lebih baik daripada siswa yang belajar dengan menggunakanpembelajaran konvensional. Belum ada penelitian yang mengkaji pengaruh model pembelajaran talking stick yang dipadukan dengan mind mapping terhadap kemampuan komunikasi matematika siswa. Berdasarkan hal tersebut, dipandang perlu untuk mendapatkan bukti empiris tentang pengaruh model pembelajaran kooperatif talking stick berbantuan mind mapping terhadap kemampuan komunikasi matematika siswa. 


\section{METODE PENELITIAN}

Penelitian ini merupakan eksperimen semu (quasi experiment). Penelitian semu dapat digunakan untuk melihat pengaruh yang ditimbulkan dari perlakuan berbeda yang diberikan pada masing-masing kelompok, dalam hal ini peneliti tidak dapat mengontrol semua variabel dan kondisi eksperimen secara ketat (Sugiyono, 2010). Populasi dalam penelitian ini yaitu siswa kelas VIII SMP Negeri 6 Singaraja non unggulan semester genap tahun ajaran 2015/2016 berjumlah 293 siswa yang terdistribusi ke dalam 10 kelas. Kesepuluh kelas tersebut setara secara akademik karena dalam pengelompokan siswa ke dalam kelas-kelas, siswa disebar secara acak dan proporsional antara siswa yang memiliki kemampuan tinggi, sedang, dan rendah. Pengambilan sampel dilakukan dengan teknik purposive random sampling dengan cara pengundian. Desain yang digambarkan seperti tabel 1.

Tabel 1. Desain Penelitian

\begin{tabular}{ccc}
\hline Kelompok & Perlakuan & Post-test \\
\hline Eksperimen & $\mathrm{X}$ & Y1 \\
\hline Kontrol & - & Y2 \\
\hline
\end{tabular}

Keterangan:

X : Perlakuanperlakuan berupa penerapan model pembelajaran talking stick berbantuan mind mapping

Y1 : Hasil post-test untuk kelas eksperimen

Y2 : Hasil post-test untuk kelas kontrol

Instrumen yang digunakan dalam mengumpulkan data untuk mengukur kemampuan komunikasi matematika siswa yaitu tes kemampuan komunikasi matematia berbentuk soal uraian (essay) yang memuat 3 indikator yaitu: (1) kemampuan mengeksperikan ide-ide matematika serta mendemonstrasikan-nya atau menggambarkannya secara tertulis, (2) kemampuan memahami, menginterpretasi, dan mengevaluasi ide-ide matematika secara tertulis, dan (3) kemampuan menggunakan istilah-istilah, notasi-notasi matematika dan struktur-strukturnya untuk menyajikan ide-ide matematika (NCTM, 2000). Sebelum digunakan, dilakukan pengujian validitas isi Gregory dengan melibatkan dua pakar, uji validitas empirik butir tes dengan menggunakan rumus korelasi product moment dari Carl Pearson serta uji reliabilitas menggunakan rumus alpha cronbach. Hasil uji validitas isi oleh dua pakar diperoleh skor 1 yang berarti tes kemampuan komunikasi 
matematika yang akan diujicobakan sangat valid (Gay, 2006). Hasil uji coba validitas empirik 6 butir tes menunjukkan bahwa keenam butir soal berada pada kategori valid $\left(r_{x y}>r_{\text {tabel }}\right)$. Dari enam soal tersebut dipilih 5 soal kemudian digunakan sebagai tes kemampuan komunikasi matematika siswa, dan hasil uji coba reliabilitasnya diperoleh koefisien reliabilitasnya 0,84 yang menunjukkan bahwa tes kemampuan komunikasi matematika siswa tersebut reliabel dengan tingkat reliabilitas sangat tinggi.

Pengujian hipotesis dengan menggunakan uji-t satu pihak dengan kriteria pengujian adalah tolak Ho jika $t_{h i t} \geq t_{(1-\alpha)}$, dimana $t_{(1-\alpha)(d k)}$ didapat dari tabel distribusi $\mathrm{t}$ pada taraf signifikasi $\alpha=5 \%$ dengan derajat kebebasan $\mathrm{dk}=$ $\left(n_{1}+n_{2}-2\right)$.

\section{HASIL PENELITIAN DAN PEMBAHASAN}

Data kemampuan komunikasi matematika siswa diperoleh dari post test yang telah diberikan kepada kelas eksperimen dan kelas kontrol. Adapun rangkuman hasilnya ditunjukkan pada tabel 2.

Tabel 2. Hasil Analisis Data Kemampuan Komunikasi Matematika Siswa pada Kelompok Eksperimen dan Kelompok Kontrol

\begin{tabular}{clcc}
\hline \multirow{2}{*}{ No } & \multirow{2}{*}{ Variabel } & \multicolumn{2}{c}{ Kelompok } \\
\cline { 3 - 4 } & & Eksperimen & Kontrol \\
\hline 1 & Banyak Siswa $(\mathrm{n})$ & 28 & 30 \\
\hline 2 & Rata-rata $(\overline{\mathrm{Y}})$ & 65,57 & 58,53 \\
\hline 3 & Standar Deviasi $(\mathrm{s})$ & 11,867 & 13,765 \\
\hline
\end{tabular}

Berdasarkan hasil analisis data pada tabel 2, terlihat bahwa bahwa ratarata skor kemampuan komunikasi matematika siswa kelompok eksperimen yang belajar dengan menggunakan model pembelajaran talking stick berbantuan mind mapping lebih tinggi dari rata-rata skor kemampuan komunikasi matematika siswa kelompok kontrol yang mengikuti pembelajaran konvensional.

Untuk mengetahui apakah kemampuan komunikasi matematika siswa yang belajar dengan menggunakanmodel pembelajaran talking stick berbantuan mind mapping lebih baik dari kemampuan komunikasi matematika siswa yang mengikuti pembelajaran konvensional, maka perlu pengujian terhadap $H_{0}$. Sebelum uji hipotesis dilakukan, terlebih dahulu dilakukan pengujian terhadap normalitas dan homogenitas varians terhadap skor 
kemampuan komunikasi matematika siswa. Rangkuman hasil uji normalitas data pada kelompok eksperimen dan kelompok kontrol dapat dilihat pada tabel 3.

Tabel 3. Rangkuman Hasil Uji Normalitas SkorKemampuan Komunikasi Matematika Siswa

\begin{tabular}{cccc}
\hline Kelompok Sampel & L $_{\text {hitung }}$ & Ltabel & Ket. \\
\hline Eksperimen & 0,12 & 0,14 & Normal \\
\hline Kontrol & 0,11 & 0,161 & Normal \\
\hline
\end{tabular}

Dari tabel 3, terlihat bahwa Lhitung pada kedua kelompok sampel baik eksperimen maupun kontrol lebih kecil dari Ltabel pada kelompok yang bersangkutan, sehingga $H_{0}$ diterima dengan kesimpulan bahwa data kemampuan komunikasi matematika siswa berasal dari populasi yang berdistribusi normal. Adapun rangkuman hasil pengujian homogenitas varians sebaran data skor kemampuan komunikasi matematika siswa untuk kedua kelompok sampel dengan Uji-F dapat dilihat pada tabel 4.

Tabel 4. Rangkuman Hasil Uji Homogenitas Varians Skor Kemampuan Komunikasi Matematika Siswa

\begin{tabular}{|c|c|c|c|}
\hline Kelompok Sampel & Varians & $F_{\text {hitung }}$ & $\mathrm{F}_{\text {tabel }}$ \\
\hline Eksperimen & 140,85 & 134 & 1,8751 \\
\hline
\end{tabular}

Dari tabel 4 tersebut, dapat dilihat bahwa $F_{\text {hit }}<F_{\text {tabel }}$, untuk taraf signifikansi 5\%, dk penyebut $=27$ dan $\mathrm{dk}$ pembilang $=29$ Dengan demikian $H_{0}$ diterima dengan kesimpulan bahwa data kemampuan komunikasi matematika diperoleh dari populasi yang variansnya homogen.

Uji prasyarat sudah terpenuhi, maka pengujian hipotesis dapat dilakukan dengan menggunakan uji-t satu pihak. Secara statistik hipotesis tersebut dapat dirumuskan sebagai berikut.

Ho: $\mu_{1}=\mu_{2}$ melawan $H_{1}: \mu_{1}>\mu_{2}$

Ho: $\mu_{1}=\mu_{2}$ menunjukkan kemampuan komunikasi matematika siswa yang belajar dengan menggunakanmodel pembelajaran talking stick berbantuan mind mapping sama dengan kemampuan komunikasi matematika siswa yang belajar dengan menggunakan pembelajaran konvensional 
$H_{1}: \mu_{1}>\mu_{2}$ menunjukkan kemampuan komunikasi matematika siswa yang belajar dengan menggunakanmodel pembelajaran talking stick berbantuan mind mapping lebih baik daripada kemampuan komunikasi matematika siswa yang belajar dengan menggunakan pembelajaran konvensional

Keterangan:

$\mu_{1} \quad=$ rata-rata kemampuan komunikasi matematika siswa yang belajar dengan menggunakanmodel pembelajaran talking stick berbantuan mind mapping

$\mu_{2} \quad$ =rata-rata kemampuan komunikasi matematika siswa yang mengikuti pembelajaran konvensional.

Adapun rangkuman hasil uji-t data kemapuan komunikasi matematika siswa dapat dilihat pada tabel 5 .

Tabel 5. Rangkuman Hasil Hasil Uji-t Data Kemampuan Komunikasi Matematika Siswa

\begin{tabular}{lllccc}
\multicolumn{1}{c}{ Kelompok } & $\mathbf{n}$ & $\bar{Y}$ & $s_{\text {gab }}^{2}$ & $t_{\text {hitung }}$ & $t_{\text {tabel }}$ \\
\hline Eksperimen & 28 & 65,57 & \multirow{2}{*}{161,51} & 2,11 & 1,67 \\
\hline Kontrol & 30 & 58,53 & & \\
\hline
\end{tabular}

Berdasarkan hasil perhitungan pada tabel 5, diperoleh bahwa nilai $t_{\text {hitung }}>t_{\text {tabel }}$, sehingga $H_{0}$ ditolak. Dengan demikian dapat disimpulkan bahwa kemampuan komunikasi matematika siswa yang belajar dengan menggunakanmodel pembelajaran talking stick berbantuan mind mapping lebih baik daripada kemampuan komunikasi matematika siswa yang belajar dengan menggunakanpembelajaran konvensional.

Perbedaan kemampuan komunikasi matematis kedua kelompok disebabkan oleh perbedaan perlakukan yang diberikan. Berdasarkan hasil pengamatan selama pelaksanaan penelitian, ada dua komponen perlakukan yang menonjol yang berdampak pada peningkatan kemampuan komukasi matematis yang signifikan yaitu pengungkapan gagasan tertulis dengan mind mapping dan adanya penerapan model pembelajaran kooperatif talking stick.

Tahapan awal pembelajaran di kelas eksperimen, guru menyampaikan materi secara singkat dengan menggunakan mind mapping yang telah dibuat dan dipersiapkan sebelumnya oleh guru itu sendiri. Selanjutnya siswa secara individual mengembangkan kerangka mind mapping disampaikan guru secara lebih rinci, dituntun hingga mencapai indikator pembelajaran. Tentu saja 
untuk dapat membuat mind mapping siswa perlu membaca secara seksama materi pada sumber belajar kemudian mengintisarikan dalam diagram. Secara tidak langsung proses menuliskan kembali ke dalam bentuk mind mapping akan melatih ingatan dan meningkatkan penguatan konsep (Vitantri, 2017), meningkatkan motivasi dan kreativitas siswa (Buzan, 2009) serta meningkatkan hasil belajar siswa (B. A. Khasanah, 2017). Peningkatan pemahaman konsep, hasil belajar, motivasi belajar berdampak positif pada peningkatan kemampuan komunikasi matematis siswa. Secara khusus, (Faelasofi, Arnidha, \& Istiani, 2015) menyatakan bahwa dengan mencatat dan memetakan materi melalui mind mapping dapat meningkatkan kemampuan siswa dalam mengekspresikan ide mereka, menghubungkan topik yang baru dipelajari dengan topik yang telah dipelajari sebelumnya, dan mengorganisasikan pikiran mereka. Kemampuan mengekspresikan ide ini, merupakan aspek penting dalam kemampuan komunikasi matematis.

Tahapan berikutnya adalah tahapan diskusi secara berkelompok yang difasilitasi dengan Lembar Kerja Siswa (LKS). Penggunaan LKS sebagai focus kegiatan diskusi juga disinyalir mampu mengefektifkan kegiatan diskusi sebagaimana diungkapkan (Khasanah \& Soedjoko, 2013) yang menyatakan bahwa penggunaan LKS dapat menumbuhkembangkan kemampuan komunikasi matematika siswa. Setelah dilakukan diskusi kelompok dilanjutkan dengan diskusi secara klasikal, yang dipandu guru dengan memberikan kesempatan kepada siswa secara acak untuk bertanya/menjawab pertanyaan dilakukan dengan mengelilingkan tongkat (talking stick) sembari menyanyikan lagu. Siswa yang memegang tongkat ketika lagu yang dinyanyikan berhenti, siswa itulah yang memperoleh giliran untuk menjawab pertanyaan dari guru. Inovasi pembelajaran ini membuat siswa belajar dalam keadaan senang dan bersemangat dalam belajar matematika yang berdampak pada peningkatan aktivitas belajar, sebagaimana ditemukan juga oleh penelitian (Agung, Widiana, \& Tresnayanti, 2017) yang menyatakan bahwa pembelajran talking stick memberikan kontribusi positif terhadap aktivitas pembelajaran. Aktivitas belajar yang tinggi nantinya bermuara peningkatan hasil belajar matematika sebagaimana temuan dan (Awuy, 2015) yang menyatakan bahwa hasil belajar siswa dengan model pembelajaran kooperatif tipe talking stick berbantuan lembar kegiatan siswa lebih baik daripada ratarata hasil belajar siswa dengan model pembelajaran konvensional.

Salah satu aspek kemampuan yang tercakup dalam hasil belajar matematika adalah kemampuan komunikasi matematis. Secara spesifik hasil 
penelitian ini telah memberikan bukti empiris bahwa pembelajaran talking stick telah memberikan pengaruh positif terhadap peningkatan kemampuan komunikasi matematis siswa. Hal ini sesuai dengan hasil penelitian sebelumnya yang telah dilakukan oleh (Sriyanti, Stick, \& Match, 2015) dan (Yunita, 2014) dengan hasil bahwa kemampuan komunikasi matematis siswa dengan model pembelajaran talking stick lebih baik dari pada kemampuan komunikasi matematis siswa dengan model pembelajaran konvensional.

Dalam penelitian ini inovasi pembelajaran yang dilakukan adalah dengan memadukan mind mapping dan model pembelajaran talking stick. Perpaduan keduanya secara empiris telah terbukti memberikan pengaruh positif terhadap peningkatan kemampuan komunikasi matematis siswa. Oleh karenanya hasil penelitian ini melengkapi hasil-hasil penelitian sebelumnya baik penelitian tentang pengaruh penggunaan mind mapping (Wowling, 2013; (Vitantri, 2017); (B. A. Khasanah, 2017) maupun pengaruh penerapan model pembelajaran talking stick (Awuy, 2015); (D. L. Khasanah \& Soedjoko, 2013); (Agung et al., 2017); (Sriyanti et al., 2015); (Yunita, 2014) dalam pembelajaran matematika.

\section{SIMPULAN}

Berdasarkan hasil dan pembahasan penelitian yang telah diuraikan, dapat disimpulkan bahwa terdapat pengaruh positif model pembelajaran talking stick berbantuan mind mapping terhadap kemampuan komunikasi matematika siswa. Kemampuan komunikasi matematika siswa dengan model pembelajaran talking stick berbantuan mind mapping lebih baik daripada kemampuan komunikasi matematika siswa dengan pembelajaran konvensional.

\section{DAFTAR PUSTAKA}

Agung, A. A. G., Widiana, I. W., \& Tresnayanti, P. I. (2017). Talking stick sebagai inovasi dalam aktivitas mengomunikasikan untuk meningkatkan pemahaman siswa. Jurnal Ilmiah Sekolah Dasar, 1 (3), 147-154. https://doi.org/10.23887/JISD.V1I3.10369

Awuy, E. (2015). Pengaruh penerapan model pembelajaran kooperatif tipe talking stick terhadap hasil belajar matematika (Studi Eksperimen pada Materi Bilangan Bulat di Kelas VII SMPN 1 Sausu).

Baroody, A. J., \& Coslick, R. T. (1992). Problem solving, reasoning, and 
communicating, K-8: Helping children think mathematically. Germany: Prentice Hall

Buzan, T. (2009). Buku pintar mind map. Jakarta: Gramedia Pustaka Utama

Depdiknas. (2006). Permendiknas nomor 22 tentang standar isi untuk satuan pendidikan dasar dan menengah. Jakarta: Depdiknas.

Faelasofi, R., Arnidha, Y., \& Istiani, A. (2015). Metode pembelajaran mind mapping untuk meningkatkan kemampuan komunikasi matematik siswa dalam pemecahan masalah matematika. Jurnal E-DuMath, 1 (2), 122-137. https:/ / doi.org/10.26638/JE.116.2064

Gay, L. R., Mills, G. E., \& Airasian, P. (2006). Educational research: Competencies for analysis and application (8th ed.). New York.

Iwan. (2004). Mengoptimalkan daya kerja otak dengan berfikir holistik dan kreatif. Jakarta: Gramedia Pustaka Utama.

Khasanah, B. A. (2017). Efektivitas model pembelajaran mind mapping menggunakan alat peraga matematika. Edumath, 3 (1), 9-14.

Khasanah, D. L., \& Soedjoko, E. (2013). Keefektifan model pembelajaran talking stick terhadap hasil belajar materi pokok aljabar. Unnes Journal of Mathematics Education, 2 (1).

Maisura, \& Jannah, R. (2016). Peningkatan kemampuan komunikasi matematis melalui model pembelajaran index card match pada materi Geometri di kelas X SMA Negeri 1 Peusangan Siblah Krueng, Jurnal Pendidikan Dasar (jupendas) 3 (1).

OECD. (2016). PISA 2015 results in focus. Oecd, (67), 16. https:/ / doi.org/10.1787/9789264266490-en

Shiel, G. e. al. (2007). PISA mathematics: A teacher's guide. Dublin: Stationery Office.

Sriyanti, A. (2015). Komparasi keefektifan pembelajaran matematika menggunakan model kooperatif tipe talking stick dengan tipe make a match pada siswa kelas VII SMP LPP UMI Makassar. MaPan : Jurnal Matematika dan Pembelajaran, 3 (1), 20-29. 
Sugiyono. (2010). Metode penelitian kuantitatif, kualitatif dan RED. Bandung: Alfabeta.

Sullvian, P. \& Mousley. (1996). Natural communication in mathematics classroom: Whats does it look like. Melbourne: Merga.

Sumarno. (2010). Berfikir dan disposisi matematik: Apa, Mengapa, dan Bagaimana dikembangkan pada peserta didik. Bandung: FMIPA UPI.

Vitantri, C. A. (2017). Integrasi concise learning method dengan mind mapping dalam pembelajaran matematika di perguruan tinggi. Beta Jurnal Tadris Matematika, 10 (2), 203-221.

Windura, S. (2008). Brain management series for learning strategys - mind map langkah demi langkah. Jakarta: PT Alex Media Komputindo.

Yunita, C. R. (2014). Pengaruh model pembelajaran talking stick terhadap peningkatan kemampuan komunikasi matematik siswa (penelitian eksperimen pada siswa kelas VII semester genap SMP Negeri 2 Tanjungsari-Sumedang. Skripsi. UIN Sunan Gunung Djati. 